Jurnal Akademika Baiturrahim Jambi, Vol 9, No. 1, Maret 2020

Doi : $10.36565 /$ jab.v9i1.190

p-ISSN: 2302-8416

e-ISSN: 2654-2552

\title{
Ketahanan Pangan Rumah Tangga dan Kejadian Kurang Energi Kronis (KEK) pada Ibu Hamil Suku Anak Dalam Desa Bungku Kabupaten Batanghari
}

\author{
Arnati Wulansari \\ Sekolah Tinggi Ilmu Kesehatan Baiturrahim \\ Email: arnatiwulansari@ rocketmail.com
}

Submitted : 13/02/2020

Accepted: 25/02/2020

Published:14/03/2020

\begin{abstract}
Chronic Energy Deficiency (CED) is the impact of poor nutritional status of pregnant women. One of determining factors that influence the nutritional status is household food security. The purpose of this study was to determine household food security and incidence of CED in pregnant women's Suku Anak Dalam in Bungku Village Batanghari Regency. This study used crossectional study design and using a total sampling of 31 pregnant women. Measuring instruments using questionnaires and CED measured using CUA ribbon and energy intake $2 \times 24$ hours measuredby recall. Data analysis were used univariate and bivariate (spearman test). The results showed that the majority of respondent experienced the risk of $C E D(67.7 \%)$. As many as $45.2 \%$ household experienced food shortages. Most of respondent who experienced food shortages also have risk of CED was $25.8 \%$. The results showed an correlation between food security and risk of CED $(P<0.05)$.
\end{abstract}

Keywords :Pregnant Women, Chronic Energy Deficiency (CED), household food security

\begin{abstract}
Abstrak
Kurang Energi Kronik (KEK) merupakan dampak dari status gizi ibu hamil yang kurang.Salah satu faktor penentu yang mempengaruhi status gizi ibu hamil adalah situasi ketahanan pangan rumah tangga.Tujuan dari penelitian ini adalah untuk mengetahui ketahanan pangan rumah tangga dan kejadian KEK pada ibu hamil Suku Anak Dalam Desa Bungku Kabupaten Batanghari.Penelitian ini menggunakan desaincross sectional studydengan menggunakan total sampling yaitu sebanyak 31 orang ibu hamil. Alat ukur menggunakan kuesioner dan KEK diukur dengan menggunakan pita LILA dan asupan energi diukur dengan menggunakan recall $2 \times 24$ jam. Analisis data dilakukan secara univariat dan bivariate (spearman test).Hasil penelitian menunjukkan bahwa sebagian besar responden mengalami risiko KEK (67.7\%).Sebanyak 45.2\% rumah tangga mengalami kurang pangan.Sebagian besar responden yang mengalami kurang pangan juga memiliki risiko KEK sebanyak 25.8\%.Hasil penelitian juga menunjukkan adanya hubungan antara ketahanan pangan dan risiko KEK $(\mathrm{P}<0.05)$.
\end{abstract}

Kata kunci :Ibu hamil, kurang energi kronik (KEK), ketahanan pangan rumah tangga

\section{PENDAHULUAN}

Kehamilan merupakan investasi dan perkembangan dimasa selanjutnya. Pada sumberdaya manusia yang sangat tinggi. masa ini juga membutuhkan asupan zat gizi Masa kehamilan merupakan periode penting yang baik dan harus tercukupi (Young et al. dalam daur hidup manusia dikarenakan 2014). Untuk itu pemenuhan gizi sangat terjadi pertumbuhan dan perkembangan janin penting karena berkaitan status gizi ibu yang yang akan berpengaruh pada pertumbuhan mempengaruhi kesehatan ibu dan bayi yang 
akan dilahirkan nanti. Status gizi ibu hamil yang kurang dapat menyebabkan berat bayu lahir rendah dan bahkan kematian ibu.Sebaliknya jika terjadi gizi lebih pada ibu hamil juga berdampak pada risiko obesitas, diabetes, dan penyakit tidak menular lainnya saat dewasa (Aviram, 2011; Ramakrishnan, 2012).

Pentingnya memperhatikan status gizi ibu hamil dilakukan untuk mencegah terjadinya masalah gizi.Masalah gizi yang sering dialami oleh ibu hamil adalah Kurang Energi Kronis (KEK). Sebanyak 24.2\% dan $23.0 \%$ ibu hamil berisiko mengalami KEK tahun 2013 berturut-turut di Indonesia dan Provinsi Jambi (Kementerian Kesehatan RI, 2013). Prevalensi KEK pada ibu hamil dari waktu ke waktu mengalami peningkatan yang cukup mengkhawatirkan.

Berdasarkan data yang diperoleh dari Puskesmas Bungku (2018) pada 3 bulan terakhir, sebanyak $7.5 \%$ ibu hamil Suku Anak Dalam (SAD) mengalami KEK (6 dari 45 orang ibu hamil) (Puskesmas Pembantu Desa Bungku, 2017). SAD merupakan masyarakat adat yang masih memegang teguh adat dan masih mempercayai mitos terkait kehamilan. Terjadinya perubahan fungsi hutan sebagai mata pencaharian dan sumberdaya pangan bagi masyarakat SAD Desa Bungku menyebabkan perubahan aktivitas nafkah dan meningkatkan risiko terjadinya kerawanan pangan (Sulistyoningrum, 2015). SAD yang tinggal Desa Bungku Kabupaten Batanghari merupakan kelompok kedua terkecil jumlahnya (79 KK) dibandingkan SAD yang menyebar di Kabupaten lain seperti Sarolangun (1093 KK), Merangin (865 KK), Tebo (822 KK), dan Bungo (289 KK) (BPS, 2017). Mengingat pentingnya status gizi bagi ibu hamil maupun janin, maka peneliti tertarik untuk melakukan studi mengenai ketahanan pangan rumah tangga kaitannya dengan status gizi ibu hamil Suku Anak Dalam di Desa Bungku Kabupaten Batanghari.Oleh Karena itu penelitian ini bertujuan untuk menganalisis ketahanan pangan rumah tangga dan status gizi ibu hamil.

\section{METODE PENELITIAN}

Penelitian ini menggunakan desain cross sectional study dilaksanakan pada bulan Januari-Juli 2019.Penelitian ini dilakukan di Desa Bungku, Kabupaten Batanghari.Populasi pada penelitian ini adalah ibu hamil di Desa Bungku yang merupakan masyarakat adat Suku Anak Dalam (SAD) yang berjumlah 31 orang ibu hamil. Penelitian ini menggunakan total sampling untuk penarikan contoh. Lingkup penelitian ini cukup kecil karena ingin melihat ketahanan pangan rumah tangga dan status gizi ibu hamil SAD yang masih memegang teguh adat dan sedang terjadi perubahan fungsi hutan yang mempengaruhi mata pencaharian dan sumberdaya pangan keluarga SAD.

Data primer yang dikumpulkan pada penelitian ini diantaranya data mengenai karakteristik subjek, Lingkar Lengan Atas (LILA), karakteristik sosial ekonomi keluarga, dan konsumsi pangan rumah tangga Suku Anak Dalam di Desa Bungku.Data karakteristik berupa pendapatan, pekerjaan, tingkat pendidikan, besar keluarga, besar pengeluaran pangan dan non pangan yang dikumpulkan melalui wawancara menggunakan kuesioner terstruktur. Data konsumsi pangan dikumpulkan menggunakan kuesioner recall $2 \times 24$ jam pada seluruh anggota keluarga.

Data ketahanan pangan rumah tangga diperoleh menggunakan metode Maxwell yang mengukur secara kuantitatif dengan mencerminkan akses ekonomi dan konsumsi 


\begin{tabular}{llcc}
\hline No Karakteristik Individu & $\mathrm{n}$ & $\%$ \\
\hline $1 \quad$ Usia (tahun) & & \\
& $17-28$ & 21 & 67.7 \\
& $29-38$ & 10 & 32.3 \\
\hline 2 & Usia Gestasional & & \\
& (minggu) & & \\
& Trimester I & 7 & 22.6 \\
& Trimester II & 19 & 61.3 \\
& Trimester III & 5 & 16.1 \\
\hline 3 & Jarak Kehamilan & & \\
& (tahun) & & \\
& $1-2$ & 10 & 32.3 \\
& $>2$ & 21 & 67.7 \\
\hline 4 & Ukuran Lila & & \\
& Kurang (<23.5) & 21 & 67.7 \\
& Normal ( $\geq 23.5)$ & 10 & 32.3 \\
\hline
\end{tabular}

pangan rumah tangga.Tingkat pengeluaran rumah tangga merupakan perbandingan biaya yang dikeluarkan untuk pangan oleh suatu rumah tangga dengan total pengeluaran rumah tangga per bulan. Untuk data konsumsi rumah tangga diperoleh dengan menggunakan recall 2x24 jam pada seluruh anggota rumah tangga sehingga diperoleh Tingkat Kecukupan Energi (TKE) rumah tangga.Pengolahan data dilakukan menggunakanMicrosoft Office Excel for Windows 2010 dan dianalisis dengan SPSS 22.0.Uji Spearman dilakukan untuk mengetahui hubungan variabel ketahanan pangan rumah tangga dan kejadian KEK pada ibu hamil.

\section{HASIL DAN PEMBAHASAN}

Penelitian ini melibatkan 31 orang ibu hamil.Sebagian besar ibu hamil (67.7\%) berada pada rentang usia 17-28 tahun dengan rata-rata usia ibu hamil adalah 26.0 06.1 tahun. Distribusi ibu hamil yang memasuki usia gestasional trimester II sebanyak $61.3 \%$. Jarak kehamilan sebagian besar yaitu lebih dari 2 tahun (67.7\%) (Tabel 1).
Tabel 1 Sebaran ibu hamil berdasarkan karakteristik individu

Salah satu faktor penyebab tidak langsung yang mempengaruhi status gizi ibu hamil adalah faktor sosial ekonomi keluarga.Hasil penelitian menunjukkan bahwa seluruh suami dan istri (100\%) memiliki lama pendidikan kurang dari 12 tahun atau tidak tamat sekolah dasar.Seluruh rumah tangga bekerja di sektor pertanian yaitu petani karet dan kebun sawit (100\%).Menjadi petani sawit bagi rumah tangga SAD seperti tidak ada pilihan karena lingkungan dan tanah adat mereka sebagian besar telah ditanami sawit oleh perusahaan.Dengan memanen sawit milik perusahaan, rumah tangga SAD bisa mendapatkan uang untuk memenuhi kebutuhan rumah tangga.Pendapatan yang diterima oleh rumah tangga $\mathrm{SAD}$ adalah $<\mathrm{Rp}$. 2000.000 (100\%).Sebagian besar rumah tangga memiliki besar keluarga tergolong kecil (<4 orang) (67.7\%).

\begin{tabular}{|c|c|c|c|}
\hline No & Karakteristik Individu & $\mathrm{n}$ & $\%$ \\
\hline \multirow[t]{3}{*}{1} & Pendidikan suami (tahun) & & \\
\hline & $<12$ & 31 & 100 \\
\hline & $\geq 12$ & 0 & 0 \\
\hline \multirow[t]{3}{*}{2} & Pendidikan istri (tahun) & & \\
\hline & $<12$ & 31 & 100 \\
\hline & $\geq 12$ & 0 & 0 \\
\hline \multirow[t]{3}{*}{3} & Pekerjaan suami & & \\
\hline & Pertanian & 31 & 100 \\
\hline & Non pertanian & 0 & 0 \\
\hline \multirow[t]{3}{*}{4} & $\begin{array}{l}\text { Pendapatan per kapita rumah } \\
\text { tangga (per bulan) }\end{array}$ & & \\
\hline & $<$ Rp. 2000.000 & 31 & 100 \\
\hline & $\geq$ Rp. 2000.000 & 0 & 0 \\
\hline \multirow[t]{3}{*}{5} & Besar keluarga (orang) & & \\
\hline & $\operatorname{Kecil}(\leq 4)$ & 21 & 67.7 \\
\hline & Sedang (5-6) & 7 & 22.6 \\
\hline
\end{tabular}


$\operatorname{Besar}(\geq 7)$

$3 \quad 9.7$

Tabel 3 Sebaran pengukuran LILA

\begin{tabular}{lcc}
\hline LILA $(\mathrm{cm})$ & $\mathrm{n}$ & $\%$ \\
\hline Kurang $(<23.5)$ & 21 & 67.7 \\
Normal $(\geq 23.5)$ & 10 & 32.3 \\
\hline
\end{tabular}

Kejadian KEK responden ditentukan berdasarkan ukuran lingkar lengan atas (LILA) saat ini. Tabel 3 menunjukkan bahwa ibu hamil sebagaian besar tergolong kurang (67.7\%) dengan LILA yang diperoleh $<23,5$ $\mathrm{cm}$. Nilai maksimum ukuran LILA pada responden adalah $27 \mathrm{~cm}$, minimumnya adalah $21 \mathrm{~cm}$ dan ukuran rata-ratanya adalah $23 \mathrm{~cm}$. Hasil pengukuran LILA ibu hamil pada penelitian ini tergolong kurang dari $23.5 \mathrm{~cm}$ (67.7\%). Hal ini menandakan bahwa ukuran LILA responden kurang dan berisiko terjadinya Kurang Energi Kronik (KEK). KEK pada ibu hamil dapat menyebabkan risiko dan komplikasi seperti anemia, infeksi dan berat badan ibu tidak bertambah secara normal, persalinan sulit dan lama, persalinan sebelum waktunya (premature), perdarahan setelah persalinan serta persalinanan dengan operasi cenderung meningkat. Dampak KEK tidak hanya terjadi pada ibu hamil, tetapi pada janin juga akan terjadi gangguan proses pertumbuhan janin sehingga dapat menimbulkan keguguran, tetanus, infeksi hematologi, kematian neonatal, cacat bawaan, asfeksia, dan BBLLR (Monita, 2016).

Indikator lainnya yang diukur dalam penelitian ini adalah ketahanan pangan rumah tangga.Ketahanan pangan rumah tangga diukur dengan menggunakan indikator Maxwell dengan memperhitungkan pengeluaran dan tingkat konsumsi energi rumah tangga.Sebagian besar subjek tergolong kurang pangan (45.2\%) dan sebanyak $25.8 \%$ memiliki risiko KEK. Hasil penelitian menunjukkan adanya hubungan antara kejadian KEK ibu hamil berdasarkan LILA dengan ketahanan pangan berdasarkan Maxwell $(P$-Value $=0.028)$. Ketahanan pangan merupakan suatu keadaan dimana semua orang setiap saat harus memiliki akses baik secara fisik dan ekonomi terhadap pangan yang cukup untuk memenuhi kebutuhan diet untuk menuju kehidupan produktif dan sehat.Berdasarkan hasil studi yang dilakukan pada 31 orang ibu hamil SAD dapat diketahui bahwa sebagian besar rumah tangga ibu hamil SAD mengalami kurang pangan.Hal ini menandakan sebagian besar memiliki proporsi pengeluaran pangan yang rendah $(<60 \%)$ dan kurang mengonsumsi energi $(<80 \%)$.Hal ini disebabkan adanya faktor pemenuhan akses pangan yang terhambat.Sebagian besar ibu hamil pada rumah tangga SAD ini tidak ikut bekerja di kebun, sehingga untuk pemenuhan akses pangan mengandalkan tukang sayur yang mendatangi daerah mereka.Akses untuk mencapai desa Bungku ini cukup sulit jika terjadi hujan terus menerus, karena kontur tanah yang sangat liat dan licin menyebabkan kendaraan terkadang tidak dapat menjangkau daerah mereka. Faktor lain yang dapat menyebabkan akses pangan mereka kurang dan terhambat adalah tidak adanya alat untuk penyimpanan bahan makanan sebagai stok atau cadangan untuk hari berikutnya ketika tidak dapat mengakses pangan segar dari luar. Hal ini juga dikarenakan akses listrik yang belum sampai ke daerah mereka, sehingga apabila memiliki alat penyimpanan bahan makanan seperti lemari es, tidak dapat digunakan.Mereka hanya dapat mengonsumsi makanan seadanya dan tidak jarang hanya mengonsumsi nasi dan garam yang diolah menjadi bubur nasi.Jumlah yang dikonsumsi pun tidak lebih dari 200 gram beras per hari.Hal ini yang menyebabkan kurangnya 
konsumsi energi terutama sumber karbohidrat.Dampak dari permasalahan tersebut cukup besar baik bagi ibu hamil maupun balita SAD tersebut.

Desa Bungku merupakan daerah pedesaan yang letaknya berada ditepi kawan hutan berjenis fungsi hutan produksi.Permasalahan pangan yang mereka alami saat ini juga diperparah dengan adanya alih fungsi lahan menjadi tanaman monokultur yaitu kelapa sawit menyebabkan perubahan aktivitas nafkah pada masyarakat Desa Bungku.Banyak SAD yang merupakan penduduk asli Desa Bungku berpindah tempat karena adanya hal tersebut.Saat ini lokasi tempat tinggal mereka menjorok jauh ke pedalaman karena terdesak oleh masuknya perkebunan sawit dari perusahaan yang masuk ke wilayah tanah adat mereka. Hal ini menjadi salah satu alasan terbesar sulitnya akses pangan bagi masyarakat SAD Desa Bungku (Sulistyoningrum, 2015).

Tabel 4. Ketahanan Pangan Rumah Tangga menurut Maxwell

\begin{tabular}{lcc}
\hline Ketahanan Pangan & n & \% \\
\hline Tahan Pangan & 10 & 32.2 \\
Rentan Pangan & 0 & 0 \\
Kurang Pangan & 14 & 45.2 \\
Rawan Pangan & 7 & 22.6 \\
\hline Total & 31 & 100 \\
\hline \multicolumn{4}{c}{ Distribusi } & ketahanan & pangan \\
berdasarkan status gizi ibu hamil & han \\
menunjukkan bahwa 25.8\% tergolong kurang \\
pangan dan memiliki risiko terjadinya \\
KEK.Hasil penelitian menunjukkan adanya \\
hubungan antara status gizi ibu hamil \\
berdasarkan LILA dengan ketahanan pangan \\
berdasarkan Maxwell (P-Value < 0.05). Hal \\
ini sejalan dengan penelitian yang dilakukan \\
oleh Na et al. (2015; 2017) bahwa ibu hamil \\
dengan rumah tangga rawan pangan \\
cenderung memiliki LILA yang rendah. \\
$\begin{array}{l}\text { Penelitian tersebut hanya membagi kategori } \\
\text { ketahanan pangan menjadi dua yaitu rawan }\end{array}$
\end{tabular}

pangan dan tahan pangan. Lebih lanjut lagi apabila ibu hamil dengan rumah tangga rawan pangan juga berisiko melahirkan bayi dengan berat badan lahir rendah (Grilo, 2015). Namun begitu, pada penelitian ini masih memiliki kekurangan yaitu menggunakan recall 2x24 jam dengan tidak memperhitungkan makanan yang dikonsumsi diluar rumah (tidak dimasak di rumah).

\section{SIMPULAN}

Sebagian besar responden berusia 17-28 tahun $(67.7 \%)$ dan masih pada usia kehamilan trimester II (61.3\%). Mayoritas jarak kehamilan lebih dari 2 tahun dan memiliki ukuran Lila kurang dari $23.5 \mathrm{~cm}$ (67.7\%).Sebanyak 100\% responden memiliki pendidikan $<12$ tahun dan bekerja dibidang pertanian dengan upah kurang dari Rp. 2000.0000.Sebanyak $67.7 \%$ memiliki besar keluarga tergolong kecil.Sebagian besar rumah tangga memiliki risiko KEK dan kurang pangan menurut Maxwell (25.8\%).Ada hubungan antara ketahanan pangan Maxwell berdasarkan status gizi $(\mathrm{P}<0.05)$.

\section{DAFTAR PUSTAKA}

Aviram A, Hod M, Yogev Y. Maternal obesity: Implications for pregnancy outcome and long-term risks-a link to maternal nutrition. Int $\mathbf{J}$ Gynecol Obstet. 2011;115(SUPPL. 1). doi:10.1016/S0020-7292(11)00541-8

BPS. Batanghari Dalam Angka 2017. Jambi; 2017.

Grilo SA, Earnshaw VA, Lewis JB, et al. Food matters: Food insecurity among pregnant adolescents and infant birth outcomes. J Appl Res Child. 2015;6(2).

Kementerian Kesehatan RI. Riset Kesehatan Dasar (National Health Survey) 2013. Jakarta : Kementerian Kesehatan RI; 2013.

Monita F, Suhaimi D, Ernalia Y. Hubungan Usia, Jarak Kelahiran dan Kadar 
Hemoglobin Ibu Hamil dengan Kejadian Berat Badan Lahir Rendah di RSUD Arifin Achmad Provinsi Riau. Jom FK. 2016;3(1):1-17.

$\mathrm{Na}$ M, Gross AL, West KP. Validation of the food access survey tool to assess household food insecurity in rural Bangladesh Biostatistics and methods. BMC Public Health. 2015;15(1):1-10. doi:10.1186/s12889-015-2208-1

Na M, Caswell BL, Talegawkar SA, Palmer A. Monthly food insecurity assessment in rural mkushi district, Zambia: A longitudinal analysis. BMC Public Health. 2017;17(1):1-8. doi:10.1186/s12889-017-4176-0

Puskesmas Pembantu Desa Bungku. Laporan Puskesmas Pembantu Bungku 2017.

Ramakrishnan U, Grant F, Goldenberg T, Zongrone A, Martorell R. Effect of women's nutrition before and during early pregnancy on maternal and infant outcomes: A systematic review. Paediatr Perinat Epidemiol. 2012;26(SUPPL. 1) :285-301. doi:10.1111/j.1365-3016.2012.01281.x

Sulistyoningrum SS. Hubungan Pola Penguasaan Sumberdaya rumahtangga dengan Ketahanan Pangan di Desa Bungku, Jambi [Skripsi]. Bogor : Institut Pertanian Bogor; 2015.

Young SL, Plenty AHJ, Luwedde FA, et al. Household food insecurity, maternal nutritional status, and infant feeding practices among HIV-infected Ugandan women receiving combination antiretroviral therapy. Matern Child Health J. 2014;18(9):2044-2053. doi:10.1007/s10995-014-1450-y 